\title{
TITLE:
}

\section{Oxygen Electrode Reaction in a LiCl-KCl Eutectic Melt}

$\operatorname{AUTHOR(S):~}$

Kado, Yuya; Goto, Takuya; Hagiwara, Rika

\section{CITATION:}

Kado, Yuya ... [et al]. Oxygen Electrode Reaction in a LiCl-KCl Eutectic Melt. Journal of The Electrochemical Society 2009, 156: E167.

\section{ISSUE DATE:}

2009

URL:

http://hdl.handle.net/2433/255613

\section{RIGHT:}

This is the Accepted Manuscript version of an article accepted for publication in Journal of The Electrochemical Society The Electrochemical Society and IOP Publishing Ltd are not responsible for any errors or omissions in this version of the manuscript or any version derived from it. The Version of Record is available online at

https://doi.org/10.1149/1.3212844.; この論文は出版社版でありません。引用の際には出版社版をご確認ご利用くださ $\iota_{0}$; This is not the published version. Please cite only the published version. 


\title{
Oxygen electrode reaction in a $\mathrm{LiCl}-\mathrm{KCl}$ eutectic melt
}

\author{
Yuya Kado, Takuya Goto*, Rika Hagiwara** \\ Department of Fundamental Energy Science, Graduate School of Energy Science, \\ Kyoto University, Yoshida-honmachi, Sakyo-ku, Kyoto 606-8501, Japan
}

*Corresponding author

Phone : +81-774-65-6676 Fax : No Fax

Email : tgoto@mail.doshisha.ac.jp

**Electrochemical Society Active member 


\begin{abstract}
Oxygen electrode reaction was investigated on a boron-doped diamond electrode in a $\mathrm{LiCl}-\mathrm{KCl}$ eutectic melt. The standard formal potential of $\mathrm{O}_{2} / \mathrm{O}^{2-}$ decreases with the elevation of temperature. The potential at $773 \mathrm{~K}$ is $2.424 \pm 0.003 \mathrm{~V}$ vs. $\mathrm{Li}^{+} / \mathrm{Li}$. The standard formal free energy change increases with the temperature elevation, calculated to be $-456.4 \pm 0.5 \mathrm{~kJ} \mathrm{~mol}^{-1}$ at $773 \mathrm{~K}$. The standard formal entropy change and enthalpy change are determined to be $-151 \pm 3 \mathrm{~J} \mathrm{~K}^{-1} \mathrm{~mol}^{-1}$ and $-573.5 \pm 0.1 \mathrm{~kJ} \mathrm{~mol}^{-1}$, respectively, at $773 \mathrm{~K}$.
\end{abstract}

Keywords: boron-doped diamond electrode; oxygen evolution; standard formal potential 


\section{Introduction}

Reduction processes of metal oxides in molten chlorides have been proposed for the production of these metals [1-4]. Oxide ion generated as a by-product in the electrolytes is known as a strong Lewis base. It affects the passivation phenomena on the surface of the produced metals [5] and plays an important role in acid-base reactions [6,7]. In order to understand chemical and electrochemical behavior of oxide ion in molten chlorides, it is necessary to determine the thermodynamic quantities of oxide ion such as chemical potentials in molten chlorides.

On the basis of these backgrounds, some researchers have reported on the oxygen electrode reaction as predictively expressed by the following equation [8-10].

$$
\frac{1}{2} \mathrm{O}_{2}+2 \mathrm{e}^{-}=\mathrm{O}^{2-}
$$

However, the obtained results were not simply applied for the oxygen electrode reaction of eq. 1. Consequently, it was suggested that the oxygen electrode reaction was influenced by the presence of the peroxide ion, $\mathrm{O}_{2}{ }^{2-}$, or the superoxide ion, $\mathrm{O}_{2}{ }^{-}$. The standard formal potential of $\mathrm{O}_{2} / \mathrm{O}^{2-}$ was investigated in a $\mathrm{LiCl}-\mathrm{KCl}$ eutectic melt at 723 $\mathrm{K}$. The value calculated from the solubility of refractory metal oxides by Masuko et al. was $2.97 \mathrm{~V}$ (vs. $\mathrm{Li}^{+} / \mathrm{Li}$ ) [7] while that estimated from the electromotive force (EMF) by 
Kanzaki et al. using a platinum electrode as an anode was $2.453 \mathrm{~V}\left(\mathrm{vs} . \mathrm{Li}^{+} / \mathrm{Li}\right)$ [11]. We have also recently estimated it to be $2.472 \pm 0.001 \mathrm{~V}$ (vs. $\mathrm{Li}^{+} / \mathrm{Li}$ ) from the solubility of $\mathrm{Li}_{2} \mathrm{O}$ determined for a $\mathrm{LiCl}-\mathrm{KCl}$ eutectic melt [12]. These results do not coincide within experimental error. One of the conceivable reasons is inaccurate measurement of the equilibrium potential because an ideally polarizable electrode (IPE) has not been available under oxygen atmosphere at high temperatures. Platinum anodes dissolve in the positive potential regions and also react with oxide ion to form lithium platinate in molten $\mathrm{LiCl}$ and platinum oxide $\left(\mathrm{Pt}_{3} \mathrm{O}_{4}\right)$ in molten $\mathrm{CaCl}_{2}$ [2]

$$
\begin{aligned}
& \mathrm{Pt} \rightarrow \mathrm{Pt}^{2+}+2 \mathrm{e}^{-} \\
& 2 \mathrm{Li}^{+}+\mathrm{Pt}+3 \mathrm{O}^{2-} \rightarrow \mathrm{Li}_{2} \mathrm{PtO}_{3}+4 \mathrm{e}^{-} \\
& 3 \mathrm{Pt}+4 \mathrm{O}^{2-} \rightarrow \mathrm{Pt}_{3} \mathrm{O}_{4}+8 \mathrm{e}^{-}
\end{aligned}
$$

It has also been reported that platinum directly reacts with the atmospheric oxygen gas to form platinum oxide $\left(\mathrm{PtO}_{2}\right)$ [13]. Therefore it is highly probable that a mixed potential measured for a platinum anode affected the accuracy of the data in the previous studies.

From the background described above, further investigation preferably using an IPE has been required in order to improve the quality of the data. In our previous study, a boron-doped diamond (BDD) electrode was found to act as an oxygen gas 
evolution electrode in molten chloride systems [14-16].

$$
\mathrm{O}^{2-} \rightarrow \frac{1}{2} \mathrm{O}_{2}+2 \mathrm{e}^{-}
$$

Accordingly, the use of the BDD electrode as an IPE is prospective for the investigation of chemical and electrochemical behavior of oxide ion in molten salts. In the present study, the oxygen electrode reaction on the BDD electrode was investigated and the standard formal potential of $\mathrm{O}_{2} / \mathrm{O}^{2-}$ was determined by the measurement of the EMF for the evaluation of the BDD electrode as an IPE.

\section{Experimental}

A BDD electrode (Sumitomo Electric Industries, Ltd., thickness: $20 \mu \mathrm{m}$, substrate: silicon, doped boron: 500-3000 ppm) was used as a working electrode. An aluminum plate (Nilaco Corp., 99.2\%) was employed for a counter electrode. The $\mathrm{Ag}^{+} / \mathrm{Ag}$ reference electrode was prepared by immersing a silver wire (Japan Metal Service, 99.99\%) in the melt containing $0.5 \mathrm{~mol} \% \mathrm{AgCl}$ (Wako Pure Chemical Co. Ltd., 99.5\%) and placed in a Pyrex glass tube with a thin bottom. The potential of the reference electrode was standardized against the $\mathrm{Li}^{+} / \mathrm{Li}$ redox couple.

Reagent-grade LiCl (Aldrich-APL 99.99\%) and $\mathrm{KCl}$ (Aldrich-APL 99.99\%) 
were mixed to prepare the eutectic composition $(\mathrm{LiCl}: \mathrm{KCl}=58.5: 41.5)$ and used for the melt in a high purity alumina crucible (SSA-S, NIKKATO) after vacuum drying at 573 $\mathrm{K}$ for 24 hours. $\mathrm{Li}_{2} \mathrm{O}$ (Aldrich. 97\%) was used as an oxide ion source which was directly added into the melt after vacuum drying at $453 \mathrm{~K}$ for 24 hours. All the experiments were performed in a glove box with a gas-refining instrument (MIWA, MS3-H60SN) under dried and deoxygenated atmosphere. The concentration of water and oxygen gas in the atmosphere were always monitored and kept less than $1 \mathrm{ppm}$. The eutectic composition was selected based on the reported phase diagram [17]. Electrochemical measurements were performed with the aid of an electrochemical measurement system (Hokuto Denko Corp., HZ-5000).

\section{Results and discussion}

\subsection{Oxygen electrode reaction}

Figure 1 shows cyclic voltammograms of the BDD electrode before and after the addition of $2.0 \mathrm{~mol} \% \mathrm{Li}_{2} \mathrm{O}$ into a $\mathrm{LiCl}-\mathrm{KCl}$ eutectic melt $(\mathrm{LiCl}: \mathrm{KCl}=58.5: 41.5$ mol\%) at $773 \mathrm{~K}$. Anodic currents were observed at around $3.6 \mathrm{~V} \mathrm{vs.} \mathrm{Li}^{+} / \mathrm{Li}$ before the addition of $\mathrm{Li}_{2} \mathrm{O}$, corresponding to the evolution of chlorine gas at the anode limit of the 
melt. After the addition of $\mathrm{Li}_{2} \mathrm{O}$, anodic currents were observed at around $2.5 \mathrm{~V}$ and these are attributed to the oxidation of oxide ion to form only oxygen gas, which was confirmed by gas analyses after the potentiostatic electrolysis [16]. These results are similar to those at $723 \mathrm{~K}$ in our previous study [14]. This result indicates that it is possible to use the BDD electrode as an IPE for electrochemical investigation of the oxygen electrode reaction.

From these results, it is considered that the reaction on the BDD electrode is the oxygen reduction reaction as described by the following equation.

$$
\frac{1}{2} \mathrm{O}_{2}+2 \mathrm{e}^{-}=\mathrm{O}^{2-}
$$

Its Nernstian equation is expressed as follows:

$$
E_{\mathrm{O}_{2} / \mathrm{O}^{2-}}=E_{\mathrm{O}_{2} / \mathrm{O}^{2-}}^{0}+\frac{R T}{2 F} \ln \frac{f_{\mathrm{O}_{2}}^{1 / 2}}{a_{\mathrm{O}^{2-}}}
$$

where $E_{\mathrm{O}_{2} / \mathrm{O}^{2-}}^{0}$ is the standard potential of $\mathrm{O}_{2} / \mathrm{O}^{2-}, R$; the gas constant, $T$; absolute temperature, $F$; the Faraday constant, $f_{\mathrm{O}_{2}}$; the fugacity of $\mathrm{O}_{2}$, and $a_{\mathrm{O}^{2-}}$; the activity of $\mathrm{O}^{2-}$. Equation 7 is derived from eq. 6 introducing the fugacity coefficient of $\mathrm{O}_{2}, \gamma_{\mathrm{O}_{2}}$, the activity coefficient of the $\mathrm{O}^{2-}$ anion, $\gamma_{\mathrm{O}^{2-}}$, the pressure of $\mathrm{O}_{2}, P_{\mathrm{O}_{2}}$, and the anion fraction of $\mathrm{O}^{2-}, X_{\mathrm{O}^{2-}}$.

$$
E_{\mathrm{O}_{2} / \mathrm{O}^{2-}}=E_{\mathrm{O}_{2} / \mathrm{O}^{2-}}^{0}+\frac{R T}{2 F} \ln \frac{\left(\gamma_{\mathrm{O}_{2}} P_{\mathrm{O}_{2}}\right)^{1 / 2}}{\gamma_{\mathrm{O}^{2-}} X_{\mathrm{O}^{2-}}}
$$


Consequently, $E_{\mathrm{O}_{2} / \mathrm{O}^{2-}}$ is given by the equation:

$$
E_{\mathrm{O}_{2} / \mathrm{O}^{2-}}=E_{\mathrm{O}_{2} / \mathrm{O}^{2-}}^{0^{\prime}}+\frac{R T}{2 F} \ln \frac{P_{\mathrm{O}_{2}}^{1 / 2}}{X_{\mathrm{O}^{2-}}},
$$

where $E_{\mathrm{O}_{2} / \mathrm{O}^{2-}}^{0^{\prime}}$ is the standard formal potential of $\mathrm{O}_{2} / \mathrm{O}^{2-}$, which is given by the following equation.

$$
E_{\mathrm{O}_{2} / \mathrm{O}^{2-}}^{0^{\prime}}=E_{\mathrm{O}_{2} / \mathrm{O}^{2-}}^{0}+\frac{R T}{2 F} \ln \frac{\gamma_{\mathrm{O}_{2}}^{1 / 2}}{\gamma_{\mathrm{O}^{2-}}}
$$

According to eq. $8, E_{\mathrm{O}_{2} / \mathrm{O}^{2-}}^{0^{\prime}}$ is obtained experimentally from the relationship between $E_{\mathrm{O}_{2} / \mathrm{O}^{2-}}$ and $\ln \left(P_{\mathrm{O}_{2}}^{1 / 2} / X_{\mathrm{O}^{2-}}\right)$. Therefore the dependence of the EMF of the BDD electrode on $\mathrm{O}_{2}$ pressure and $\mathrm{O}^{2-}$ concentration was investigated.

At first, the change of the EMF on the BDD electrode in the melt containing $0.5 \mathrm{~mol} \% \mathrm{Li}_{2} \mathrm{O}$ was observed when oxygen gas was introduced into the cell. Figure 2 shows the changes of the EMF on the BDD electrode when oxygen pressure was changed from 0.5 to $0.7 \mathrm{~atm}$ (a) and from 0.7 to $0.5 \mathrm{~atm}$ (b). The EMF immediately responded to change when oxygen pressure was changed. This result suggests that the reaction on the $\mathrm{BDD}$ electrode is attributed to the redox of $\mathrm{O}_{2} / \mathrm{O}^{2-}$.

Figure 3 shows the logarithmic plot of the EMF against oxygen pressures from 0.05 to $0.7 \mathrm{~atm}$. It increases with the increase of oxygen pressure and changes linearly with $\log P_{\mathrm{O}_{2}}$. The slope is calculated by the least-square method and the stoichiometric 
number of electrons determined is 1.91 , which is regarded as 2 within the experimental error to be consistent with the theoretical value in eq. 8. In addition, Fig. 4 shows the logarithmic plot of the EMF against the amount of $\mathrm{Li}_{2} \mathrm{O}$ added into the melt when oxygen pressure was kept constant at $0.5 \mathrm{~atm}$. The potential shifts to the negative direction almost linearly with $\log X_{\mathrm{O}^{2-}}$ as the additive amount of $\mathrm{Li}_{2} \mathrm{O}$ increases and finally shows a constant value corresponding to the saturation of $\mathrm{Li}_{2} \mathrm{O}$ in the melt. As a result, the solubility of $\mathrm{Li}_{2} \mathrm{O}$ in a $\mathrm{LiCl}-\mathrm{KCl}$ eutectic melt at $773 \mathrm{~K}$ was determined to be $1.15 \mathrm{~mol} \%$, which is in good agreement with our previous study (1.14 $\pm 0.05 \mathrm{~mol} \%)$ [12]. Moreover, the stoichiometric number of electrons in the electrode reaction is determined to be 2.03 by a least-square method which is regarded as 2 within the experimental error and coincides with the theoretical value in eq. 8

It is concluded from these results that the reaction on the BDD electrode is the oxygen electrode reaction as expressed by eq. 1. The standard formal potential of $\mathrm{O}_{2} / \mathrm{O}^{2-}$ is determined to be $2.424 \pm 0.003 \mathrm{~V}$ vs. $\mathrm{Li}^{+} / \mathrm{Li}$ in a $\mathrm{LiCl}-\mathrm{KCl}$ eutectic melt at 773 K. The error value denotes the $95 \%$ confidence. In the same manner, the standard formal potential of $\mathrm{O}_{2} / \mathrm{O}^{2-}$ was measured 673 to $803 \mathrm{~K}$. The result is shown in Fig. 5. It decreases almost linearly with the temperature elevation and the temperature dependence is given by the following equation using a least-square method. 


$$
E_{\mathrm{O}_{2} / \mathrm{O}^{2-}}^{0^{\prime}}=2.995( \pm 0.001)-7.38( \pm 0.14) \times 10^{-4} T / \mathrm{V} \text { vs. } \mathrm{Li}^{+} / \mathrm{Li}
$$

Here the value at $723 \mathrm{~K}$ is $2.463 \pm 0.001 \mathrm{~V}$ vs. $\mathrm{Li}^{+} / \mathrm{Li}$. This result indicates that the previous study by Kanzaki et al. [11] in which the standard electrode potential was determined by the measurement of EMF using a platinum electrode was more precise than the that by the determination from the solubility of refractory metal oxides in the melt reported by Masuko et al. [7] although the influence of a mixed potential was not completely avoided on a platinum electrode as described in section 1 . It is also suggested that our previous study estimated from the $\mathrm{Li}_{2} \mathrm{O}$ solubility [12] is judged to be rather precise. This is probably due to the difference in the methods of determining the saturation point.

\subsection{Thermodynamical consideration}

In the present study, the obtained potentials were standardized against $\mathrm{Li}^{+} / \mathrm{Li}$ potential. The $\mathrm{Li}^{+} / \mathrm{Li}$ potential is described as:

$$
E_{\mathrm{Li}^{+} / \mathrm{Li}}=E_{\mathrm{Li}^{+} / \mathrm{Li}}^{0}+\frac{R T}{F} \ln a_{\mathrm{Li}^{+}}
$$

where $E_{\mathrm{Li}^{+} / \mathrm{Li}}^{0}$ is the standard potential of $\mathrm{Li}^{+} / \mathrm{Li}$ and $a_{\mathrm{Li}^{+}}$is the activity of $\mathrm{Li}^{+}$cation.

Since $E_{\mathrm{Li}^{+} / \mathrm{Li}}$ was defined to be zero in this study, $E_{\mathrm{Li}^{+} / \mathrm{Li}}^{0}$ is expressed as follows.

$$
E_{\mathrm{Li}^{+} / \mathrm{Li}}^{0}=-\frac{R T}{F} \ln \left(\gamma_{\mathrm{Li}^{+}} X_{\mathrm{Li}^{+}}\right)
$$


Here, $\gamma_{\mathrm{Li}^{+}}$is the activity coefficient and $X_{\mathrm{Li}^{+}}$is the mole fraction of $\mathrm{Li}^{+}$cation.

Accordingly, the standard potential of $\mathrm{Li}^{+} / \mathrm{Li}$ is obtained since the activity coefficient of

$\mathrm{LiCl}$ in a $\mathrm{LiCl}-\mathrm{KCl}$ eutectic melt $\left(X_{\mathrm{Li}^{+}}=0.585\right)$ is given by the following equation [18].

$$
R T \ln \gamma_{\mathrm{Li}^{+}}=-2306
$$

The standard free energy change for the reaction (14), $\Delta G^{0}(14)$, is given by eq.

15.

$$
\begin{aligned}
& 2 \mathrm{Li}+\frac{1}{2} \mathrm{O}_{2}=2 \mathrm{Li}^{+}+\mathrm{O}^{2-} \\
& \Delta G^{0}(14)=-2 F\left(E_{\mathrm{O}_{2} / \mathrm{O}^{2-}}^{0}-E_{\mathrm{Li}^{+} / \mathrm{Li}}^{0}\right)
\end{aligned}
$$

Here we introduce the standard formal free energy change, $\Delta G^{0^{\prime}}(14)$, expressed by the equation:

$$
\Delta G^{0^{\prime}}(14)=\Delta G^{0}(14)-R T \ln \frac{\gamma_{\mathrm{O}_{2}}^{1 / 2}}{\gamma_{\mathrm{O}^{2-}}}
$$

Thus, $\Delta G^{0^{\prime}}(14)$ is described as follows using the standard formal potential of $\mathrm{Li}^{+} / \mathrm{Li}$, $E_{\mathrm{Li}^{+} / \mathrm{Li}}^{0^{\prime}}$

$$
\Delta G^{0^{\prime}}(14)=-2 F\left(E_{\mathrm{O}_{2} / \mathrm{O}^{2-}}^{0^{\prime}}-E_{\mathrm{Li}^{+} / \mathrm{Li}}^{0}\right)
$$

Therefore the standard formal free energy change for the reaction (14), $\Delta G^{0^{\prime}}(14)$ is calculated from eqs. 12,13 and 17 using the mole fraction of $\mathrm{Li}^{+}$cation and $E_{\mathrm{O}_{2} / \mathrm{O}^{2-}}^{0^{\prime}}$ 
obtained in the present study. In addition, the standard formal entropy change, $\Delta S^{0^{\prime}}(14)$, and the standard formal enthalpy change, $\Delta H^{0^{\prime}}(14)$, are calculated according to eqs. 18 and 19.

$$
\begin{aligned}
& \Delta S^{0^{\prime}}(14)=-\left(\frac{\partial \Delta G^{0^{\prime}}(14)}{\partial T}\right)_{p} \\
& \Delta H^{0^{\prime}}(14)=\Delta G^{0^{\prime}}(14)+T \Delta S^{0^{\prime}}(14)
\end{aligned}
$$

The obtained formal thermodynamic quantities are given as follows.

$$
\begin{aligned}
& \Delta G^{0^{\prime}}(14)=-573.5( \pm 0.1)+151( \pm 3) \times 10^{-3} T / \mathrm{kJ} \mathrm{mol}^{-1} \\
& \Delta S^{0^{\prime}}(14)=-151( \pm 3) / \mathrm{J} \mathrm{K}^{-1} \mathrm{~mol}^{-1} \\
& \Delta H^{0^{\prime}}(14)=-573.5( \pm 0.1) / \mathrm{kJ} \mathrm{mol}^{-1}
\end{aligned}
$$

The error values denote the $95 \%$ confidence intervals. $\Delta G^{0^{\prime}}(14)$ increases as the temperature increases. $\Delta H^{0^{\prime}}(14)$ and $\Delta S^{0^{\prime}}(14)$ are constant in this temperature range.

On the other hand, the standard formal free energy change for the reaction (14), $\Delta G^{0^{\prime}}(14)$, was calculated as follows. The solution equilibrium of $\mathrm{Li}_{2} \mathrm{O}$ is described by reaction (23) and the free energy change is given by eq. 24, where $a_{\mathrm{Li}^{+}}$is the activity of the $\mathrm{Li}^{+}$cation.

$$
\begin{aligned}
& \mathrm{Li}_{2} \mathrm{O}(\mathrm{s})=2 \mathrm{Li}^{+}+\mathrm{O}^{2-} \\
& \Delta G(23)=\Delta G^{0}(23)+R T \ln \left(a_{\mathrm{Li}^{+}}^{2} a_{\mathrm{O}^{2-}}\right)
\end{aligned}
$$

When a $\mathrm{LiCl}-\mathrm{KCl}$ melt is saturated with $\mathrm{Li}_{2} \mathrm{O}$, the solution equilibrium is achieved and 
the free energy change of reaction (23) is zero. Therefore eq. 24 is rewritten by eq. 25 .

$$
\Delta G^{0}(23)=-R T \ln \left(a_{\mathrm{Li}^{+}}^{2} a_{\mathrm{O}^{2-}}\right)
$$

Here we introduce the standard formal free energy, $\Delta G^{0^{\prime}}(23)$, described by the following equation.

$$
\Delta G^{0^{\prime}}(23)=\Delta G^{0}(23)+R T \ln \left(\gamma_{\mathrm{O}^{2}}\right)
$$

Thus $\Delta G^{0^{\prime}}(23)$ is given by the following equation.

$$
\Delta G^{0^{\prime}}(23)=-R T \ln \left(\gamma_{\mathrm{Li}^{+}}^{2} X_{\mathrm{Li}^{+}}^{2} \cdot X_{\mathrm{O}^{2}}\right)
$$

This is a similar concept as the standard formal potential in eq. 9 and is calculated from our previous solubility data on $\mathrm{Li}_{2} \mathrm{O}$ [12]. Therefore the standard formal free energy change, $\Delta G^{0^{\prime}}(14)$, is calculated as follows.

$$
\Delta G^{0^{\prime}}(14)=\Delta G_{\mathrm{f}}^{0^{\prime}}\left(\text { solid } \mathrm{Li}_{2} \mathrm{O}\right)+\Delta G^{0^{\prime}}(23)
$$

Here, $\Delta G_{\mathrm{f}}^{0^{\prime}}$ (solid $\mathrm{Li}_{2} \mathrm{O}$ ) is the standard formal free energy of formation of crystalline $\mathrm{Li}_{2} \mathrm{O}$, which is available from reported thermodynamical data [19-21].

$$
2 \mathrm{Li}(\mathrm{l})+\frac{1}{2} \mathrm{O}_{2}(\mathrm{~g})=\mathrm{Li}_{2} \mathrm{O}(\mathrm{s})
$$

Figure 6 shows $\Delta G^{0^{\prime}}$ (14) obtained in the present study which increases with the elevation of temperature. The calculated values are also shown in Fig. 6 by a grey line, taking account the error values which denote the $95 \%$ confidence intervals in our previous data on $\mathrm{Li}_{2} \mathrm{O}$ solubility. As a typical result, the obtained thermodynamical 
quantities at $773 \mathrm{~K}$ are summarized in Table 1. These values are in good agreement within the experimental error, indicating the validity of successive measurements in this study.

\section{Conclusion}

The standard formal potential of $\mathrm{O}_{2} / \mathrm{O}^{2-}$ was measured precisely using the BDD electrode as an IPE in a LiCl-kCl eutectic melt. The standard formal free energy change for the reaction (14) is in good agreement with the calculated value from our solubility data on $\mathrm{Li}_{2} \mathrm{O}$ obtained previously, indicating the validity of successive measurements in this study.

$$
2 \mathrm{Li}+\frac{1}{2} \mathrm{O}_{2}=2 \mathrm{Li}^{+}+\mathrm{O}^{2-}
$$

Thus, this study has enabled thermodynamical consideration on chemical and electrochemical processes involved by oxide ion such as electrochemical reduction of metal oxides with higher accuracy than before. 


\section{References}

[1] G. Z. Chen, D. J. Fray, T. W. Farthing, Nature 407, 361 (2000).

[2] Y. Sakamura, M. Kurata and T. Inoue, J. Electrochem. Soc., 153, D31 (2006).

[3] R. O. Suzuki and K. Ono, 13th International Symposium.on Molten Salt and Ionic Liquids, Proceedings, 19, 810 (2002).

[4] T. Usami, M. Kurata, T. Inoue, H. E. Sims, S. A. Beetham, and J. A. Jenkins, J.Nucl. Mater, 300, 15 (2002).

[5] X. K. Feng and C. A. Melendres, J. Electrochem. Soc., 129, 1245 (1982).

[6] R. Littlewood, J. Electrochem. Soc., 109, 525 (1962).

[7] N. Masuko, M. Okada and T. Hisamatsu, Yoyuen, 6, 570 (1963).

[8] V. L. Cherginets, O. V. Demirskaya and T. P. Rebrova, F. Chem. Thermodynamics, 36, 115 (2004).

[9] V. L. Cherginets, Electrochim. Acta, 42, 1507 (1997).

[10] N. S. Wrench and D. Inman, J. Electroanal.Chem., 17319 (1968).

[11] Y. Kanzaki and M. Takahashi, J. Electroanal. Chem., 58, 339 (1975).

[12] Y. Kado, T. Goto and R. Hagiwara, J. Chem. Eng. Data, 53, 2816 (2008).

[13] Alcock, C. B. and Hopper, G. W., Proc. Roy. Soc., 254A, 551 (1960). 
[14] T. Goto, Y. Araki and R. Hagiwara, Electrochem. Solid-State Lett., 9, D5 (2006).

[15] Y. Kado, T. Goto and R. Hagiwara, J. Electrochem. Soc., 155, E85 (2008).

[16] Y. Kado, T. Goto and R. Hagiwara, Diamond and Relat. Mater., accepted (2009).

[17] E. Elchardus and P. Laffitte, Bull. Chim., France, 51, 1572 (1932).

[18] J. Lumsden, Thermodynamics of Molten Salt Mixtures, p.47, Academic Press, London (1966).

[19] I. Barin, Thermochemical Data of Pure Substances Part II, VCH Verlags Gesellschaft, Weinheim (1993).

[20] Glushko Thermocenter of the Russian Academy of Sciences, IVTAN Association, Izhorskaya 13/19, 127412 Moscow, Russia (1994).

[21] Landolt-Börnstein, Thermodynamic Properties of Inorganic Material, SGTE, Springer- Verlag, Berlin-Heidelberg (2001) 


\section{List of Table and Figure captions}

Table 1 Thermodynamical data (a) obtained in this study and (b) calculated data from the solubility of $\mathrm{Li}_{2} \mathrm{O}$ for the reaction (14): $2 \mathrm{Li}+1 / 2 \mathrm{O}_{2}=2 \mathrm{Li}^{+}+\mathrm{O}^{2-}$. (The error values denote the $95 \%$ confidence intervals.)

Fig.1 Cyclic voltammograms on the BDD electrode in a $\mathrm{LiCl}-\mathrm{KCl}$ eutectic melt before (a) and after (b) the addition of $2.0 \mathrm{~mol} \% \mathrm{Li}_{2} \mathrm{O}$ at $773 \mathrm{~K}$ (Scan rate: $0.1 \mathrm{~V} \mathrm{~s}^{-1}$ ).

Fig.2 The O.C.P. of the BDD electrode under oxygen pressures of 0.5 and 0.7 atm in $\mathrm{LiCl}-\mathrm{KCl}$ eutectic melt containing $0.5 \mathrm{~mol} \% \mathrm{Li}_{2} \mathrm{O}$ at $773 \mathrm{~K}$.

Fig.3 The logarithmic plots of the O.C.P. of the BDD electrode against oxygen pressures in a $\mathrm{LiCl}-\mathrm{KCl}$ eutectic melt containing $0.5 \mathrm{~mol} \% \mathrm{Li}_{2} \mathrm{O}$ at $773 \mathrm{~K}$.

Fig.4 The logarithmic plots of the O.C.P. of the BDD electrode against the amount of $\mathrm{Li}_{2} \mathrm{O}$ added into the melt under an oxygen pressure of 0.5 atm in a $\mathrm{LiCl}-\mathrm{KCl}$ eutectic melt at $773 \mathrm{~K}$.

Fig.5 Temperature dependence of the standard formal potential of $\mathrm{O}_{2} / \mathrm{O}^{2-}$ in a $\mathrm{LiCl}-\mathrm{KCl}$ eutectic melt.

Fig.6 Temperature dependence of the standard formal free energy change of the reaction 
(12): $2 \mathrm{Li}+1 / 2 \mathrm{O}_{2}=2 \mathrm{Li}^{+}+\mathrm{O}^{2-}$ in a $\mathrm{LiCl}-\mathrm{KCl}$ eutectic melt. Calculated results are shown by a grey wide line, considering the error values which denote the $95 \%$ confidence intervals in our previous data on $\mathrm{Li}_{2} \mathrm{O}$ solubility. 
Table 1 Thermodynamical data (a) obtained in this study and (b) calculated data from the solubility of $\mathrm{Li}_{2} \mathrm{O}$ for the reaction (14): $2 \mathrm{Li}+1 / 2 \mathrm{O}_{2}=2 \mathrm{Li}^{+}+\mathrm{O}^{2-}$ (The error values denote the $95 \%$ confidence intervals.)

\begin{tabular}{cccc}
\hline & $\Delta G^{0^{\prime}} / \mathrm{kJ} \mathrm{mol}^{-1}$ & $\Delta S^{0^{\prime}} / \mathrm{J} \mathrm{K}^{-1} \mathrm{~mol}^{-1}$ & $\Delta H^{0^{\prime}} / \mathrm{kJ} \mathrm{mol}^{-1}$ \\
\hline (a) & $-456.3 \pm 0.5$ & $-151 \pm 3$ & $-573.5 \pm 0.1$ \\
& & & \\
(b) & $-456.7 \pm 2.3$ & $-161 \pm 3$ & $-581.0 \pm 0.2$ \\
\hline
\end{tabular}




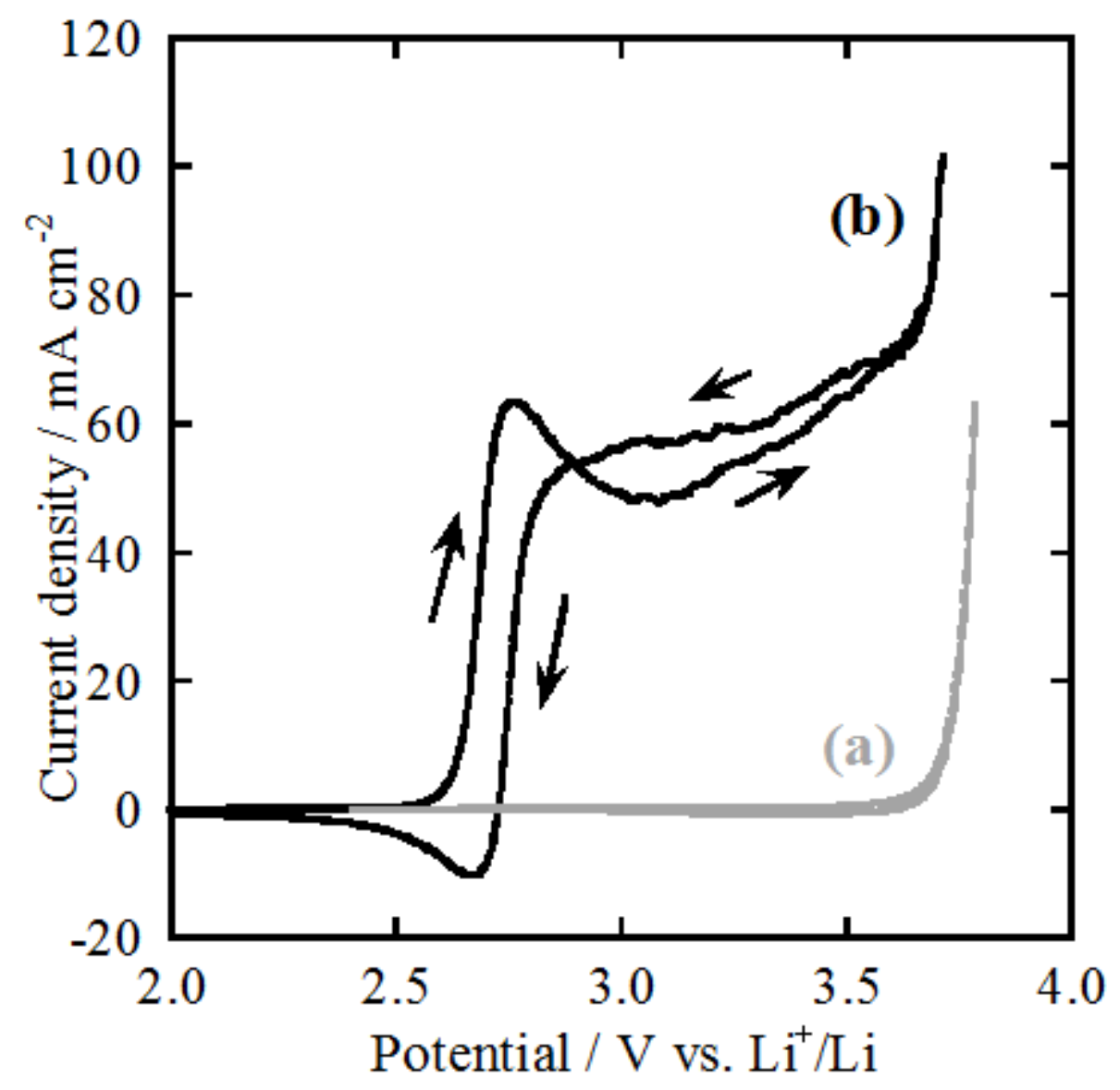

Fig.1 Cyclic voltammograms on the BDD electrode in a $\mathrm{LiCl}-\mathrm{KCl}$ eutectic melt before

(a) and after (b) the addition of $2.0 \mathrm{~mol} \% \mathrm{Li}_{2} \mathrm{O}$ at $773 \mathrm{~K}$ (Scan rate: $0.1 \mathrm{~V} \mathrm{~s}^{-1}$ ). 

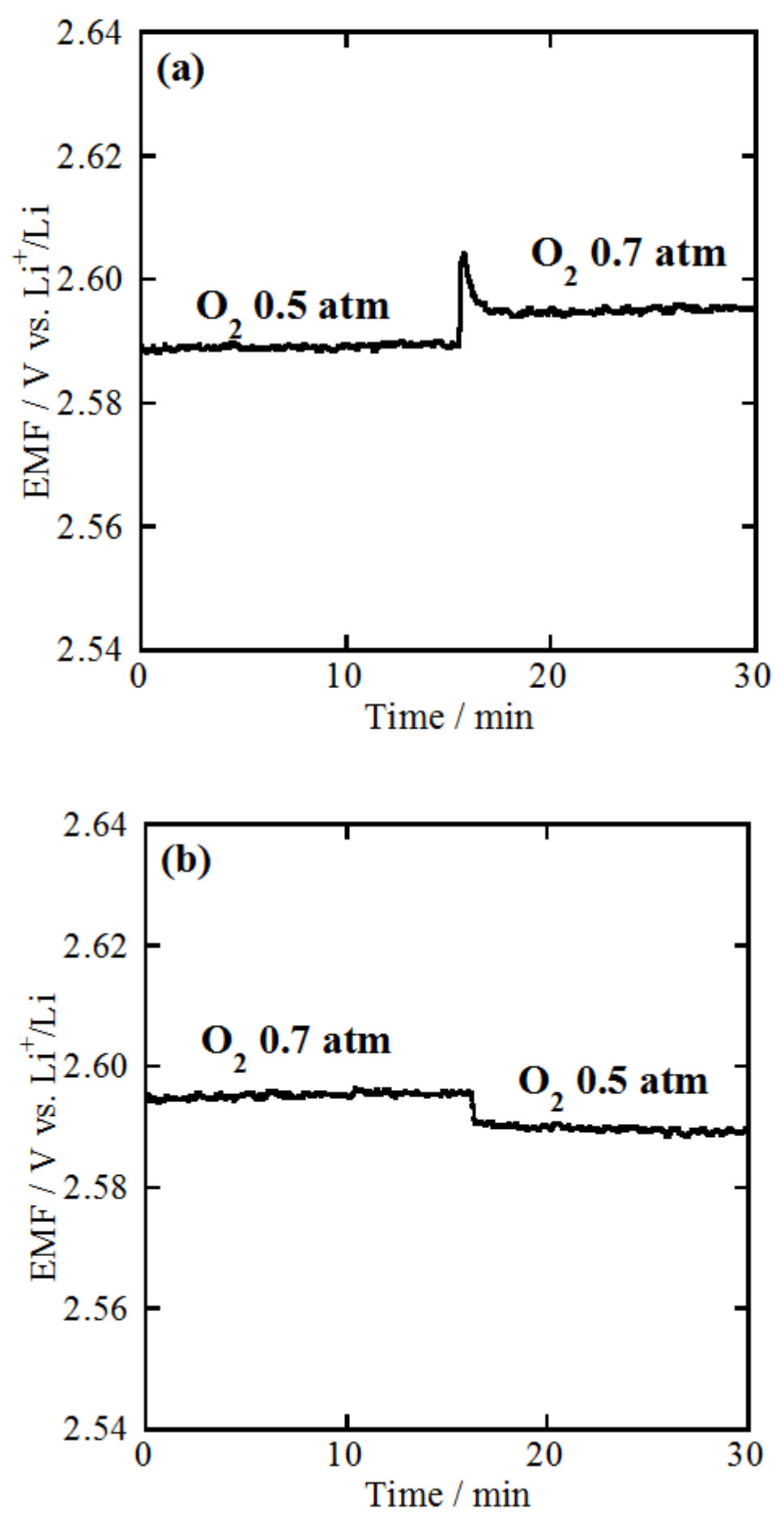

Fig.2 O.C.P. of the BDD electrode under oxygen pressures of 0.5 and 0.7 atm in a $\mathrm{LiCl}-\mathrm{KCl}$ eutectic melt containing $0.5 \mathrm{~mol} \% \mathrm{Li}_{2} \mathrm{O}$ at $773 \mathrm{~K}$. 


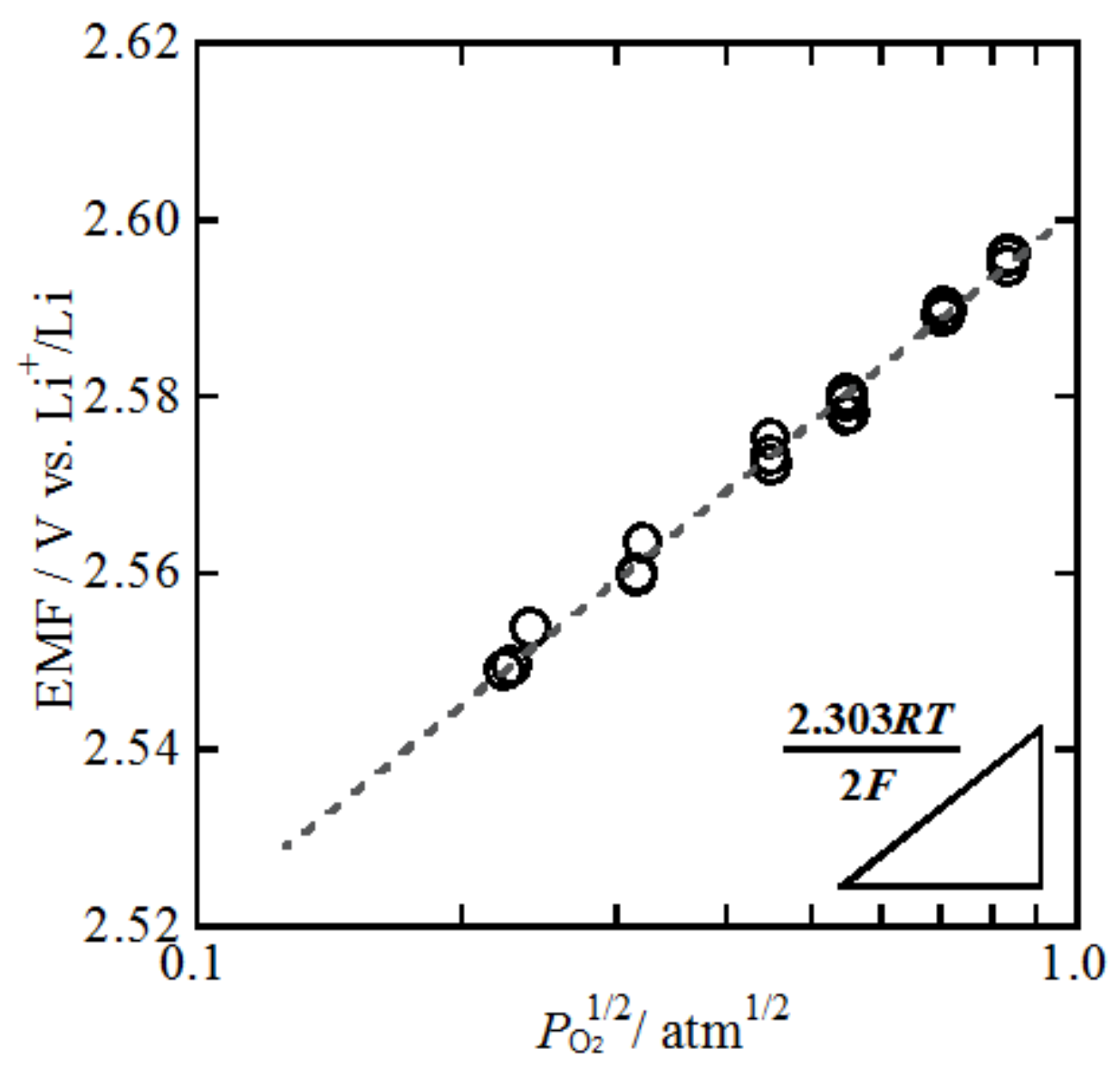

Fig.3 The logarithmic plots of the O.C.P. of the BDD electrode against oxygen pressures in a $\mathrm{LiCl}-\mathrm{KCl}$ eutectic melt containing $0.5 \mathrm{~mol} \% \mathrm{Li}_{2} \mathrm{O}$ at $773 \mathrm{~K}$. 


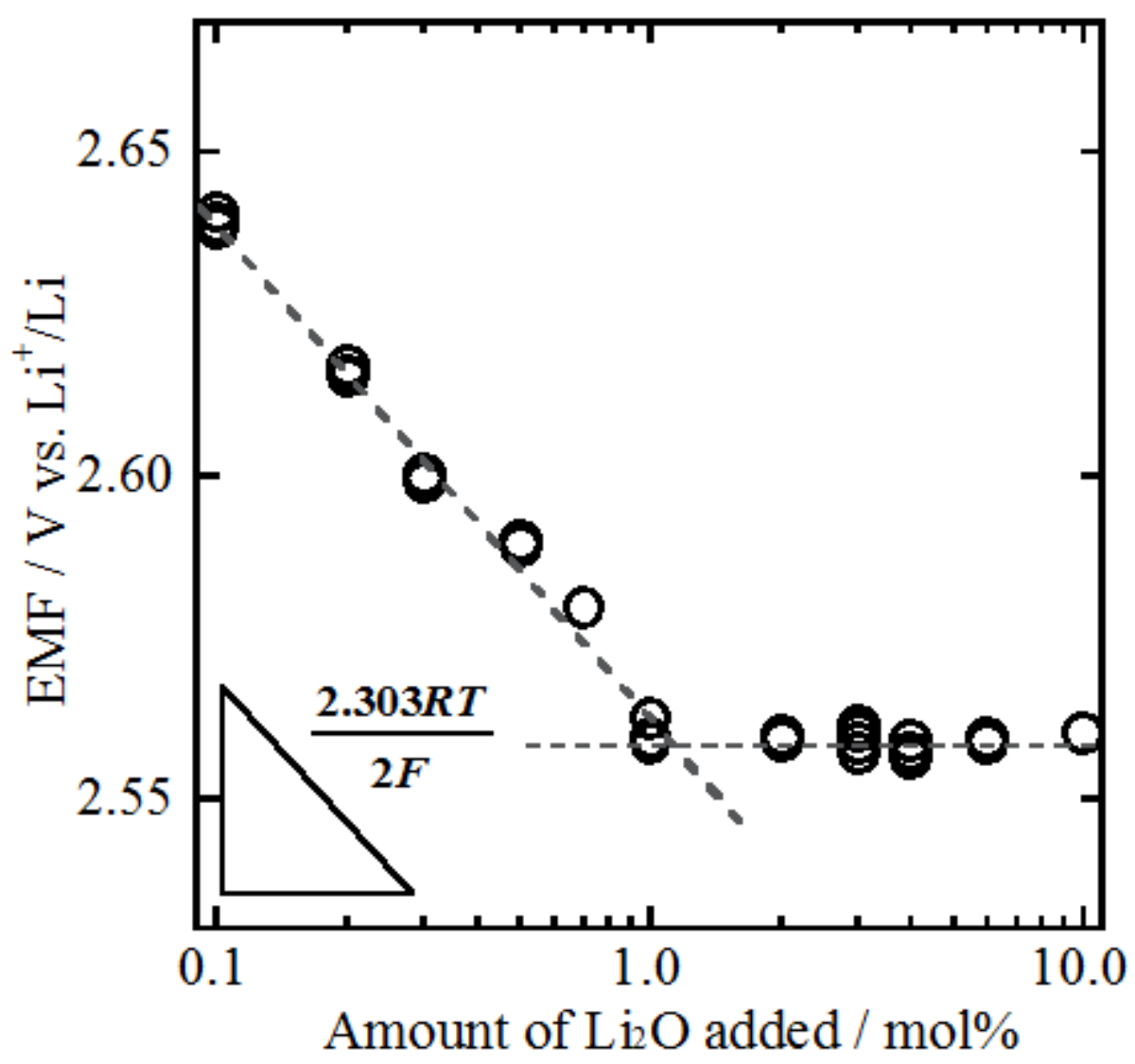

Fig.4 The logarithmic plots of the O.C.P. of the BDD electrode against the amount of $\mathrm{Li}_{2} \mathrm{O}$ added into the melt under an oxygen pressure of 0.5 atm in a $\mathrm{LiCl}-\mathrm{KCl}$ eutectic melt at $773 \mathrm{~K}$. 


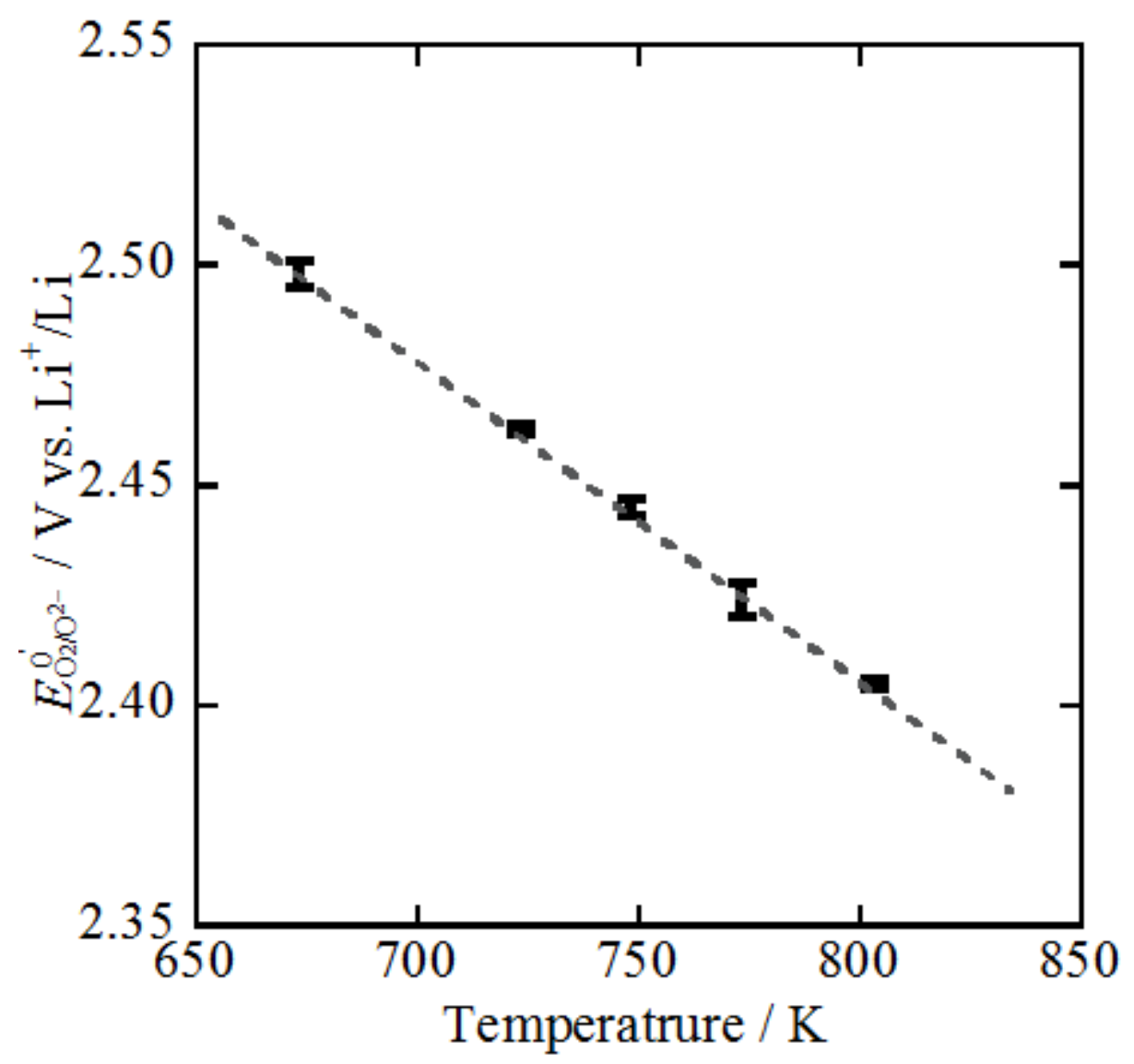

Fig.5 Temperature dependence of the standard formal potential of $\mathrm{O}_{2} / \mathrm{O}^{2-}$ in a $\mathrm{LiCl}-\mathrm{KCl}$ eutectic melt. 


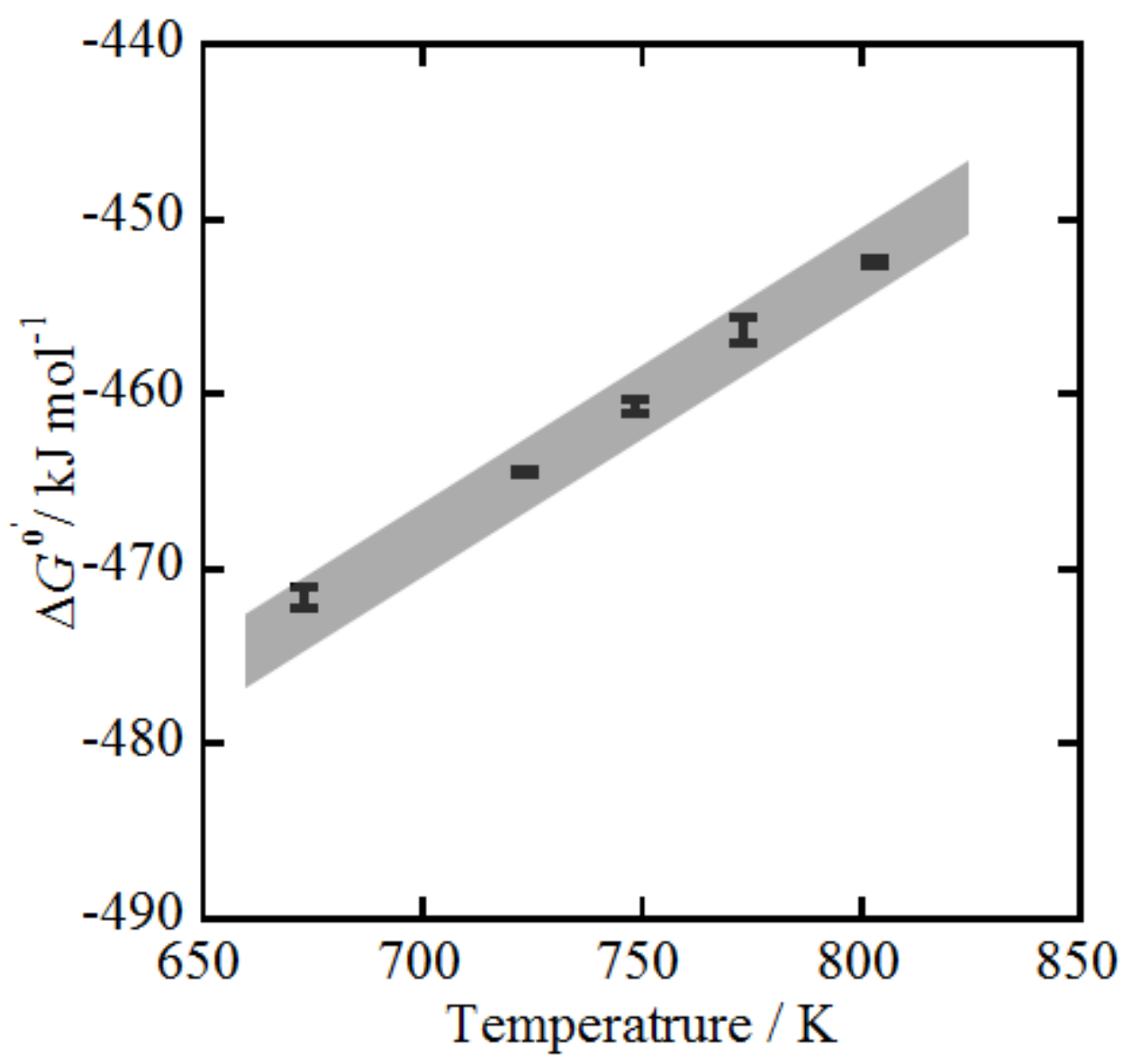

Fig.6 Temperature dependence of the standard formal free energy change of the reaction (12): $2 \mathrm{Li}+1 / 2 \mathrm{O}_{2}=2 \mathrm{Li}^{+}+\mathrm{O}^{2-}$ in a $\mathrm{LiCl}-\mathrm{KCl}$ eutectic melt. Calculated results are shown by a grey wide line, considering the error values which denote the $95 \%$ confidence intervals in our previous data on $\mathrm{Li}_{2} \mathrm{O}$ solubility. 